\title{
ANALYSIS OF A PERIOD OF ELEVATED OZONE CONCENTRATION REPORTED OVER THE VAAL TRIANGLE ON 2 JUNE 2013
}

\author{
Gregor Feig ${ }^{1 *}$, Xolile Ncipha1, Beverley Vertue ${ }^{1}$, Seneca Naidoo ${ }^{1}$, Desmond Mabaso ${ }^{1}$, Nokulunga Ngcukana', \\ Cheledi Tshehla', Njabulo Masuku'

\begin{abstract}
${ }^{1}$ Air Quality Information, South African Weather Service, 442 Rigel Avenue South Erasmusrand Pretoria 0001, ${ }^{*}$ gregor.feig@weathersa.co.za
\end{abstract}

\begin{abstract}
A peak in the ambient ozone concentration was observed at three of the six ambient air quality monitoring stations in the Vaal Triangle Airshed Priority Area on the second of June 2013. The ozone peak was associated with elevated concentrations of particulate matter, including $\mathrm{PM}_{10}, \mathrm{PM}_{2.5}$ and black carbon, but not sulphur dioxide, oxides of nitrogen, carbon monoxide nor benzene. Back trajectory analysis using Hysplit showed that the air masses containing the high levels of ozone passed over areas influenced by coal fired power stations in the Waterberg, metal processing in the Bojanala region and high intensity fires $30 \mathrm{~km}$ to $50 \mathrm{~km}$ upwind of the stations.
\end{abstract}

\section{INTRODUCTION}

Tropospheric ozone is an important pollutant. It is involved in the production of photochemical smog, particularly over metropolitan areas and has a negative impact on crop productivity (Chameides et al., 1992). It plays an important role in atmospheric chemistry, influencing the production of the $\mathrm{OH}$ radical and thereby influences the oxidative capacity of the atmosphere. Tropospheric ozone is considered to have two major sources, firstly the incursion of ozone rich stratospheric air into the troposphere and secondly the de novo synthesis. In the presence of nitrogen oxides (NOx) ozone may be produced through the photochemical oxidation of hydrocarbons or carbon monoxide (CO) (Chameides et al., 1992; Seinfeld \& Pandis, 2006). For this reaction to occur the presence of NOx, Volatile Organic Compounds (VOC) or $\mathrm{CO}$ and solar radiation is required (Chameides et al., 1992; Crutzen \& Lelieveld, 2001).

Exposure to high concentrations of ozone has been implicated in increased premature mortality and reduced respiratory function (Silva et al., 2013; WHO, 2013). Due to the importance of ozone on human health, ozone is considered a criteria pollutant in South Africa (DEA, 2009). National Standards have been set with a limit value of $61 \mathrm{ppb}$ as an eight hour running average (with 11 exceedances allowed annually). Many monitoring stations in South Africa report exceedances of the National Ambient Air Quality Standard for Ozone.

On the $2^{\text {nd }}$ of June 2013 a peak in the ambient ozone concentrations which substantially exceeded the National Ambient Air Quality Standard was observed at three of the ambient air quality monitoring stations in the Vaal Triangle Ambient Air Quality Monitoring Network (Figure 1). Due to the extremely high levels of ozone that were observed it was decided that further investigation in the origins of this ozone episode was required.

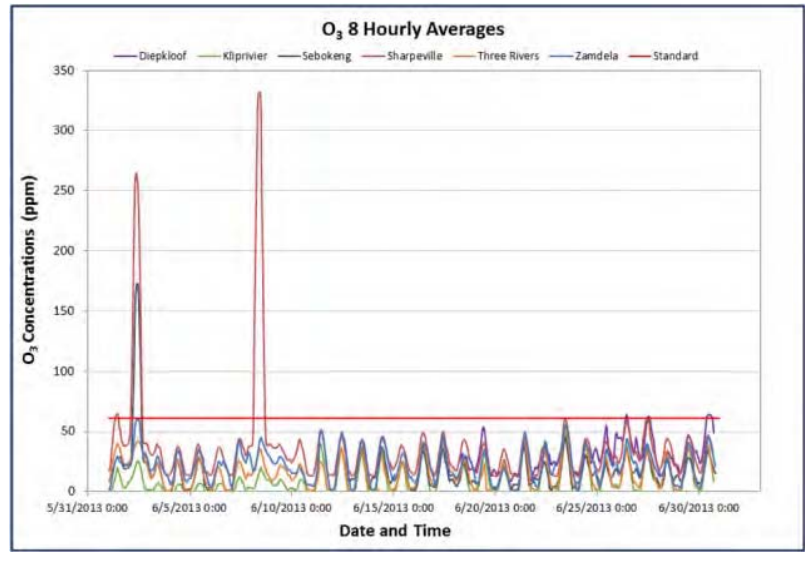

Figure 1 Time series of the 8 hour running ozone concentration for the 6 ambient air quality monitoring stations in the Vaal Triangle Priority Area Air Quality Monitoring Network

\section{Methods and Materials}

\subsection{Ambient Air Quality Monitoring Network}

The Vaal Triangle is an urban and an industrial heartland of South Africa. The combination of industrial, domestic, transport, biomass burning, agricultural and other emission sources have led to degraded air quality over the area. This in turn directly impacts on the health and well-being of people residing in the Vaal Triangle (Trade and Industry Chamber, 2004). In 2007 a network of 6 ambient air quality monitoring stations were set up in the Vaal Triangle with stations located at Diepkloof, Kliprivier, Sebokeng, Sharpeville, Three Rivers and Zamdela (Sasolburg)Figure 2. on next page. 


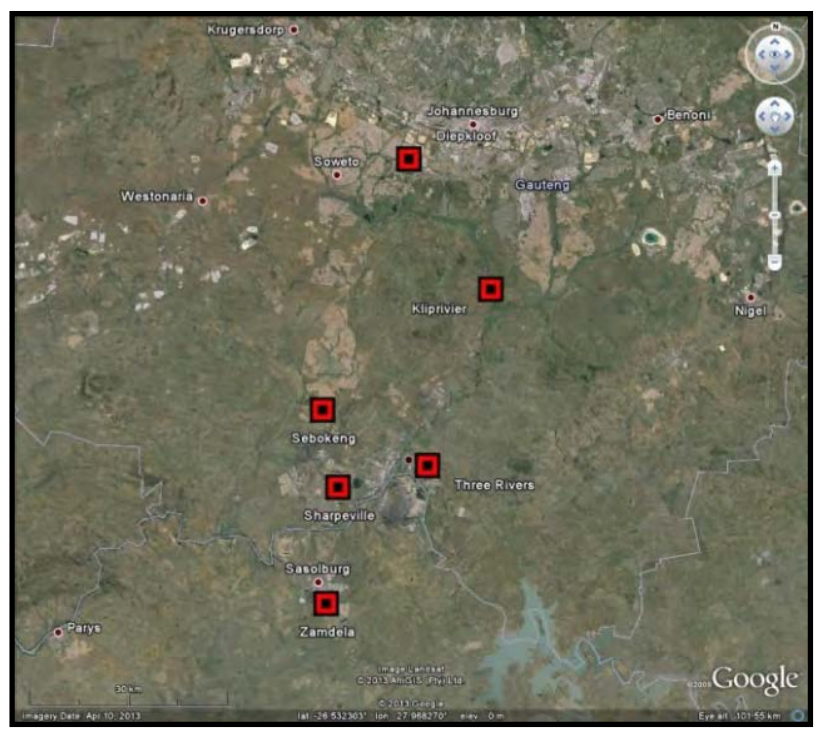

Figure 2: Google Earth image showing the location of the ambient air quality monitoring stations in the Vaal Triangle Ambient Air Quality Monitoring Network

Each of the stations is equipped with instrumentation for the measurement of meteorological parameters and for the measurement of atmospheric chemical constituents ( Table 1). In addition, the Zamdela station is equipped with a Thermo Electron MultiAngle Absorption Photometer instrument (MAAP) for the measurement of atmospheric black carbon. All instrumentation is regularly calibrated according to the SANAS TR07-03 requirements (SANAS, 2012) using certified calibration gas traceable to the national reference standard (Air Liquid) and a Thermo Electron 146i Multigas Calibrator. At the time of the period of high ozone concentration on the $2^{\text {nd }}$ of June the instrument at Diepkloof was offline for repairs, therefore the Diepkloof station will not be considered in this analysis.

Table 1 Instrumentation for measurement of Atmospheric Chemical Constituents

\begin{tabular}{|c|c|c|c|}
\hline $\begin{array}{c}\text { Paramet } \\
\text { er }\end{array}$ & Model & $\begin{array}{c}\text { Minimum } \\
\text { Detection } \\
\text { Limit }\end{array}$ & $\begin{array}{c}\text { Averaging } \\
\text { Period }\end{array}$ \\
\hline $\begin{array}{c}\mathrm{PM}_{10} \text { and } \\
\mathrm{PM}_{2.5}\end{array}$ & $\begin{array}{c}\text { Thermo } \\
\text { Electron FH62 } \\
\text { C14 }\end{array}$ & $1 \mu \mathrm{g} / \mathrm{m}^{3}$ & 5 minutes \\
\hline $\mathrm{SO}_{2}$ & $\begin{array}{c}\text { Thermo } \\
\text { Electron Model } \\
43 \mathrm{I}\end{array}$ & $1 \mathrm{ppb}$ & 5 minutes \\
\hline $\mathrm{CO}$ & $\begin{array}{c}\text { Thermo } \\
\text { Electron Model } \\
48 \mathrm{I}\end{array}$ & $0.04 \mathrm{ppm}$ & 5 minutes \\
\hline $\mathrm{O}_{3}$ & $\begin{array}{c}\text { Thermo } \\
\text { Electron Model } \\
49 \mathrm{I}\end{array}$ & $0.5 \mathrm{ppb}$ & 5 minutes \\
\hline $\mathrm{NO}_{\mathrm{x}}$ & $\begin{array}{c}\text { Thermo } \\
\text { Electron Model } \\
42 \mathrm{I}\end{array}$ & $0.4 \mathrm{ppb}$ & 5 minutes \\
\hline $\mathrm{BTEX}$ & $\begin{array}{c}\text { Synspec } \\
\text { GC955 Series } \\
600\end{array}$ & $0.1 \mu \mathrm{g} / \mathrm{m}^{3}$ & 15 minutes \\
\hline
\end{tabular}

\subsection{Atmospheric Conditions and Trajectory analysis}

Due to the importance of atmospheric conditions, on the formation and movement of ozone and ozone precursors, an analysis of the atmospheric conditions at the time of the ozone exceedance was conducted. The synoptic charts for the central regions of South Africa were obtained from the South African Weather Service and information relating to the upper air was obtained for the balloon assent of the $2^{\text {nd }}$ of June 2013 at the Irene Weather Station located approximately $100 \mathrm{~km}$ to the north east of the Vaal Triangle.

To assess the possible source locations of ozone precursors back trajectory analysis was performed using the Hysplit model for a 24 hour back trajectory. An ending height of $100 \mathrm{~m}$ above ground level was chosen.

\subsection{Remote Sensing of fire locations}

The fire map was downloaded from Advanced Fire Information System (AFIS) at http://southernafrica.afis.co.za. The system gives the near real-time and historical satellite-based fire monitoring information, covering multiple regions across the globe. The fires are detected by sensors on-board the Earth observation satellites, NASA MODIS and EUMETSAT MSG. A query was made on fires that occurred in southern Africa over a period of 24 hours on 2 June 2013, (i.e. fires that occurred during 2 June 2013 00:00 and 3 June 00:00) and the study area was zoomed into. AFIS then gives geographic location of fires and their intensity represented by different colours, yellow representing low, orange medium, red high and deep red extreme intensity(Van Rooi, 2012).

\section{Results}

\subsection{Ozone Concentration 2 June 2013}

The analysis of the 5 minute averaged ozone data from the stations at Sharpeville, Kliprivier, Sebokeng, Zamdela and Three Rivers stations (Figure 3) shows that a peak in the recorded ozone concentration occurred between $\sim 9: 00$ and $\sim 16: 00$ at the Sebokeng, Sharpeville and Zamdela Stations. At the Three Rivers and Kliprivier Stations this period of elevated ozone concentration was not observed. The maximum 5 minute ozone concentration recorded was 957 ppb for Sharpeville at 12:45, $784 \mathrm{ppb}$ at Sebokeng at 13:05, $336 \mathrm{ppb}$ at Zamdela at 12:40. Three Rivers and Kliprivier, which did not experience the period of elevated ozone concentration, had maximum concentrations of $51 \mathrm{ppb}$ and $32 \mathrm{ppb}$ at $14: 00$ and 14:30, respectively (Figure 3 ). The timing of the maximum ozone concentration at the stations showing the incident of high ozone is slightly earlier than at the other two stations. The ozone concentration at the Eskom owned Waterworks Station, located in the Vaal Triangle Region showed a 
maximum ozone concentration of $218 \mathrm{ppb}$ during the same time period. In all of the stations the concentration of ozone returned to the normal levels by approximately 16:00.

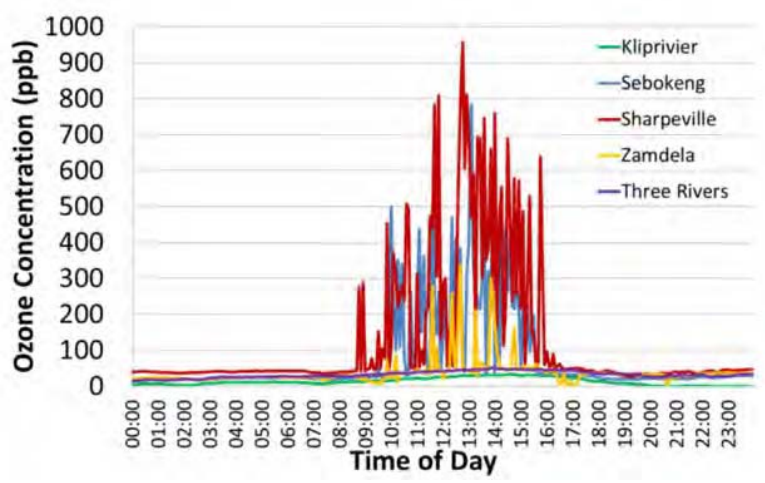

Figure 3 Time Series of ozone concentration ( 5 minute average) recorded on the 2 June 2013 at the Vaal Triangle Stations.

\subsection{Other Chemical Parameters}

The ambient concentration of $\mathrm{PM}_{10}$ at the three stations where the elevated ozone occurred showed an approximate 5 fold elevation during the period from 10:00 to $15: 00$ (Figure 4). A peak 5 minute $\mathrm{PM}_{10}$ concentration of $464 \mu \mathrm{g} / \mathrm{m}^{3}$ was observed at Sharpeville at 13:20, 35 minutes after the maximum recorded ozone concentration, but well within the period of elevated ozone. The elevation of the $\mathrm{PM}_{10}$ concentrations was much less pronounced at Three Rivers and Kliprivier which did not display the elevation in ozone concentration.

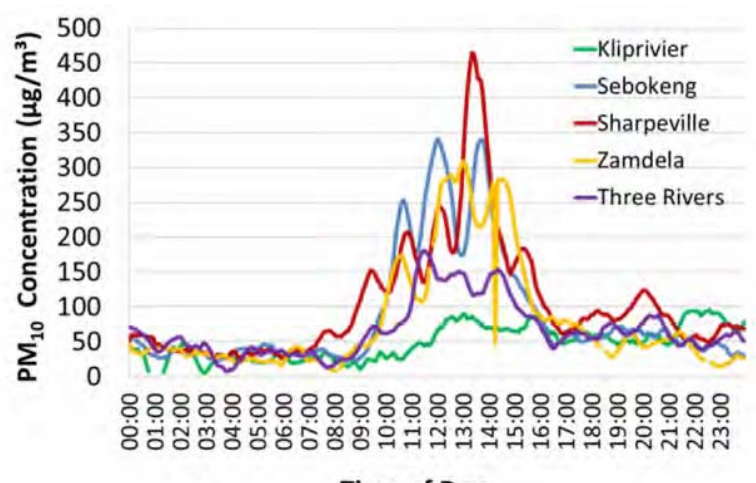

Time of Day

Figure 4 Time Series of $\mathrm{PM}_{10}$ Concentration $\left(\mu \mathrm{g} / \mathrm{m}^{3}\right)$ on the 2nd June 2013 for the Vaal Triangle monitoring Network.

The concentrations of $\mathrm{PM}_{2.5}$ at Zamdela, Sharpeville and Sebokeng showed an approximate threefold increase during the hours of 10:00 to $15: 00$ coinciding with the period of elevated ozone concentration. This elevation in $\mathrm{PM}_{2.5}$ was not as pronounced in the Three Rivers and Kliprivier stations.

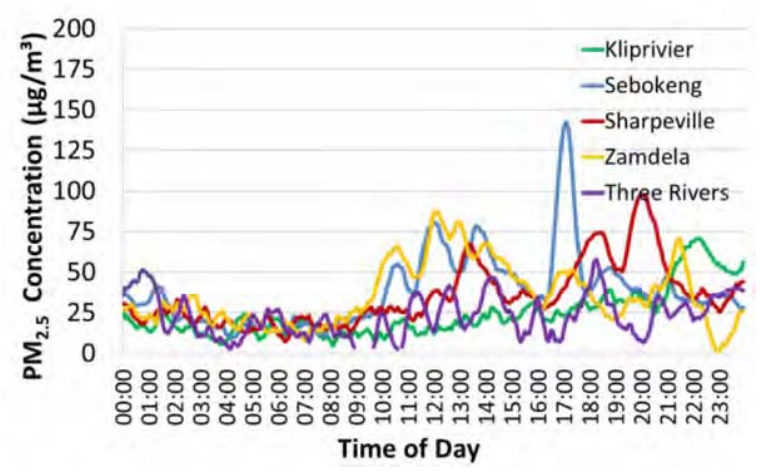

Figure 5 Time Series of $\mathrm{PM}_{2.5}$ concentration $\left(\mu \mathrm{g} / \mathrm{m}^{3}\right)$ on the second of June 2013 for the Vaal Triangle Monitoring Network.

Black carbon is a strong indicator for combustion. During the period of elevated ozone, the black carbon concentration increased from approximately $1 \mu \mathrm{g} / \mathrm{m}^{3}$ to approximately $3 \mu \mathrm{g} / \mathrm{m}^{3}$, this is during the part of the day when the concentration of black carbon is expected to decrease as the atmosphere is more thoroughly mixed and localized sources of combustion such as domestic burning are not as prevalent as they would be during the evening and early morning hours. The elevation of the black carbon concentration that would typically be expected in the early evenings and that is associated with domestic burning is seen from approximately 18:00.

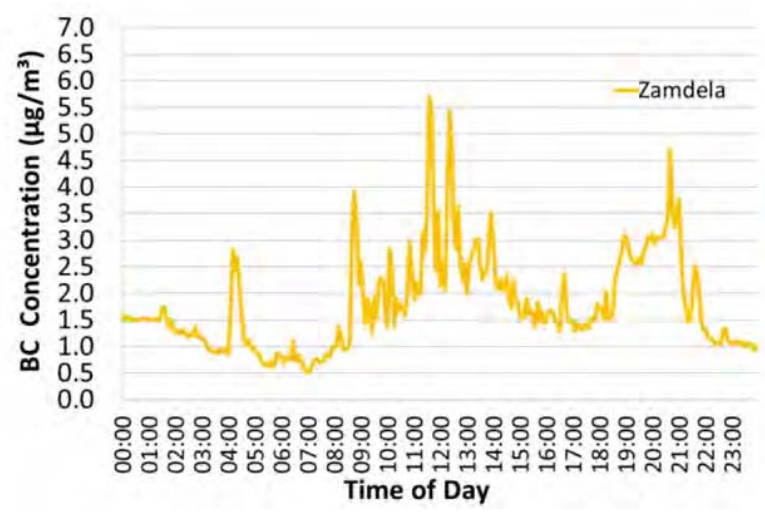

Figure 6 Time Series of Black Carbon concentration $\left(\mu \mathrm{g} / \mathrm{m}^{3}\right)$ on the second of June 2013 for the Zamdela Station

During the period of the peak in ozone there is a strong increase in the ratio of $\mathrm{PM}_{10}$ to black carbon, which is not seen for the ratio of $\mathrm{PM}_{2.5}$ to black carbon. This implies that during this period there was a change in the composition of the particulate matter with an increase in the large size fractions (Figure 7). Figure on next page. 


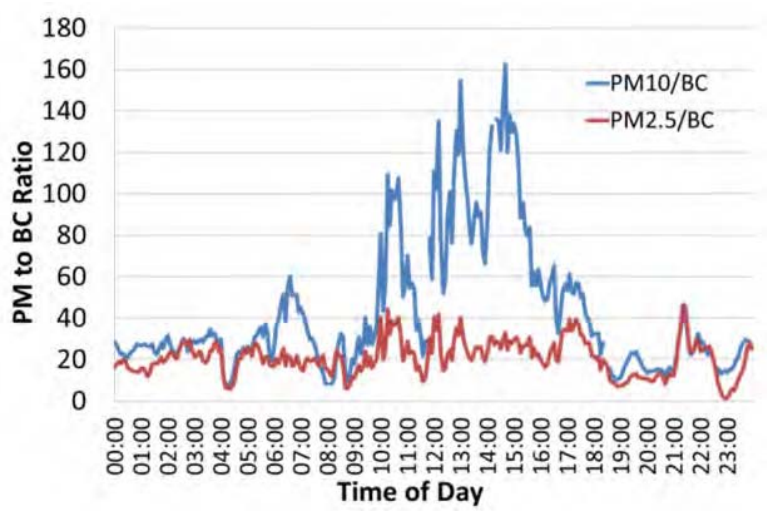

Figure 7 Time series of the ratio of particulate matter to black carbon on the second of June at the Zamdela station.

The concentration of $\mathrm{SO}_{2}$ (Figure 8) which is often considered to be an indicator of industrial activity did not show any consistent increase during the period of elevated ozone concentration. Peaks in the $\mathrm{SO}_{2}$ concentration were observed at Zamdela which are likely to be associated with local industrial emissions from the industrial operations to the north of the monitoring station.

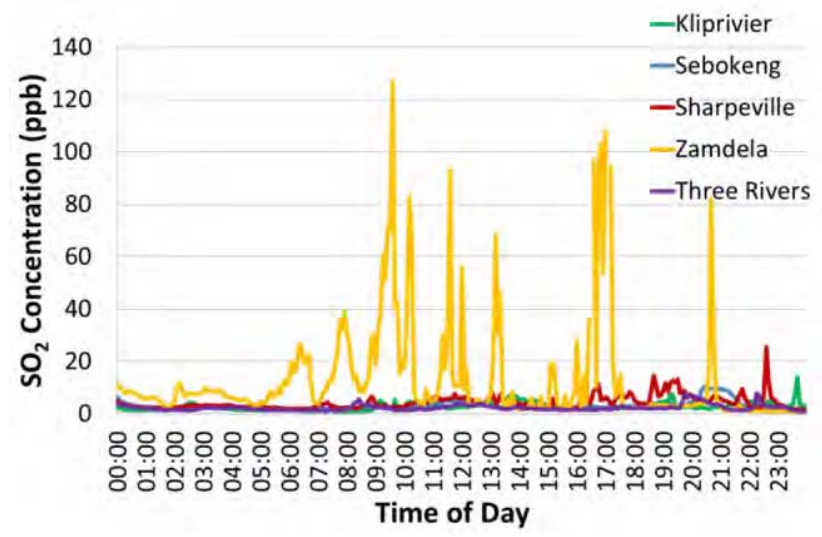

Figure 8 Time Series of $\mathrm{SO}_{2}$ concentration (ppb) on the second of June 2013 for the Vaal Triangle Monitoring Network.

The concentrations of $\mathrm{CO}$ were not elevated at any of the sites during the period of elevated ozone concentration. Increases in the $\mathrm{CO}$ concentration in the early evening are typically associated with domestic combustion activities in the low income residential areas surrounding the stations. Figure 9 on next column.

The concentration of $\mathrm{NO}_{x}$ does not show a significant elevation during the period of high ozone concentration, while there is an increase between $12: 00$ and 14:00 this does not discriminate between the stations that show higher levels of ozone and those that do not. Figure 10 on next column.

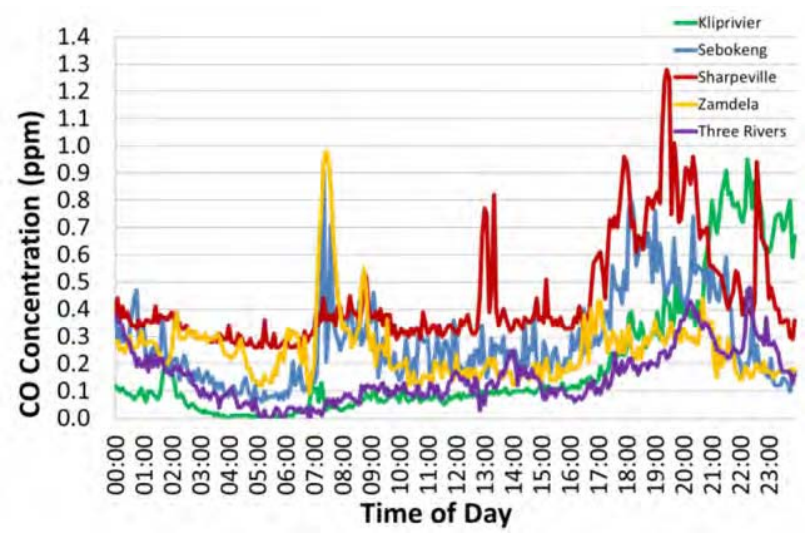

Figure 9 Time Series of CO concentration (ppb) on the second of June 2013 for the Vaal Triangle Monitoring Network.

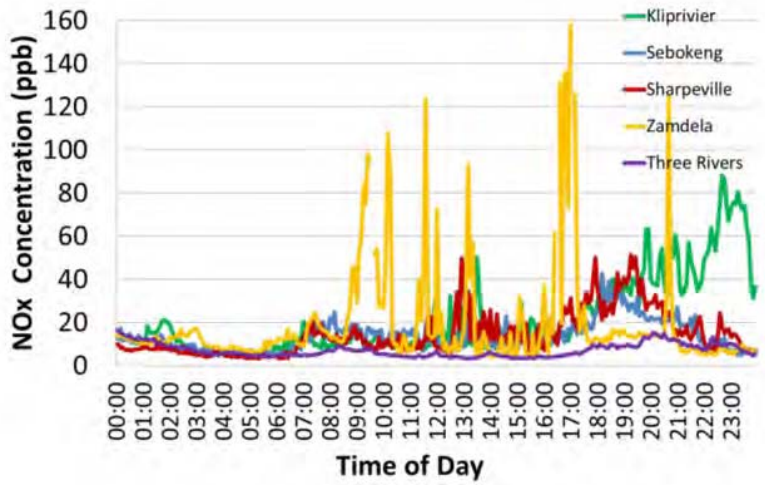

Figure 10 Time Series of NOx concentration (ppb) on the second of June 2013 for the Vaal Triangle Monitoring Network.

Analysis of the concentrations of benzene on the 2 June 2013, do not show significant changes in the benzene concentration during the period of elevated ozone concentration, a similar pattern is seen for the other VOC's measured including Xylene and Toluene.

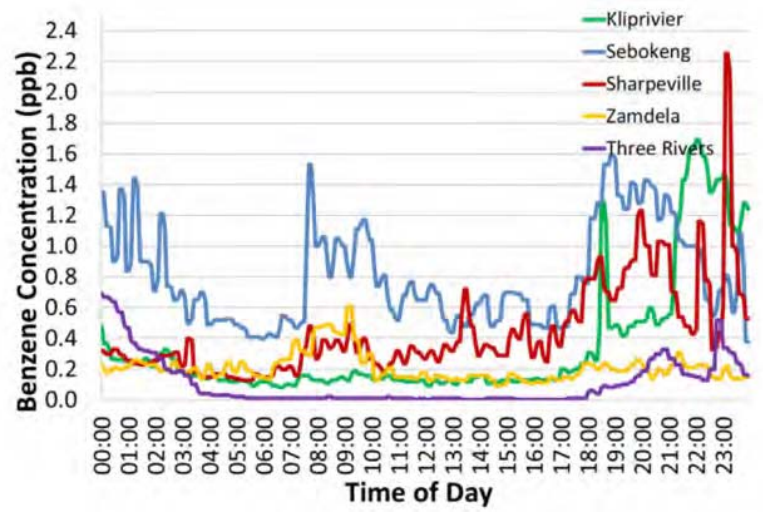

Figure 11 Time Series of Benzene concentration (ppb) on the second of June 2013 for the Vaal Triangle Monitoring Network. 


\subsection{Atmospheric Conditions over the Vaal Triangle on 2 June 2013}

During the time of the reported period of elevated ozone the synoptic conditions in South Africa were represented by a strong frontal system that was crossing the country from the south west, preceded by a surface trough extending from the north west to the south east over the interior of the country. The area ahead of the front typically experiences stable conditions with the occurrence of dry descending air. The synoptic chart for the 2 June 2013 is presented in Figure 12.

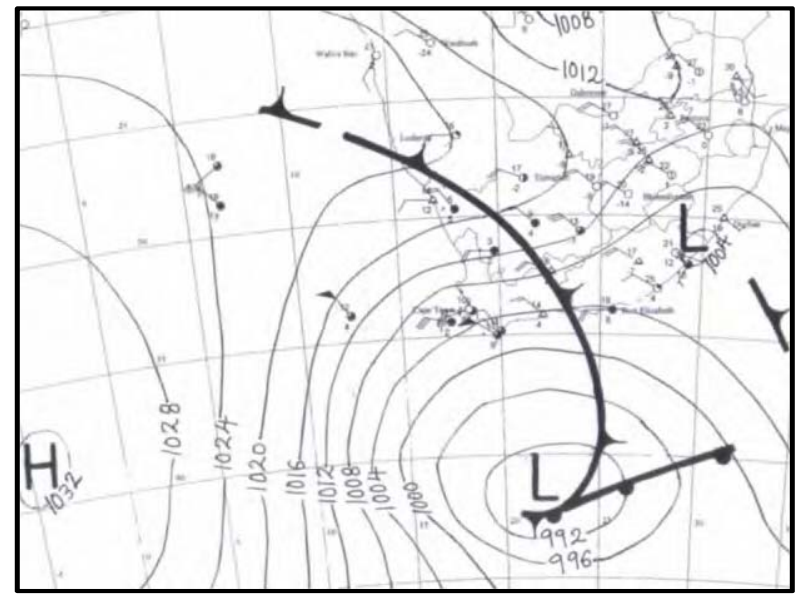

Figure 12 Synoptic chart on the 2 June 2013 14:00 SAST(SAWS, 2013)

The atmospheric profile was obtained for the upper air balloon assent on the second of June. The vertical profile taken at the Irene Station shows that there is a strong inversion layer between $2133 \mathrm{~m}$ and $2308 \mathrm{~m}$ above ground level (Figure 13). The tropopause is situated at $13000 \mathrm{~m}$ above ground level. Examination of the radiosonde measurements from the previous week indicate that the inversion was in place for a number of days prior to the reported incident.

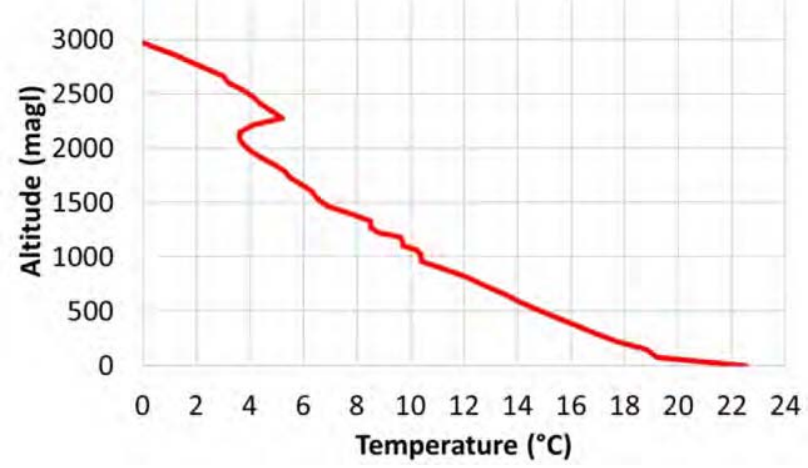

Figure 13 atmospheric temperature profile taken at the Irene weather Station

\subsection{Back trajectory and wind analysis}

A back trajectory analysis of the air mass carrying the elevated concentrations of ozone was conducted using Hysplit trajectory model where the back trajectory for a period of 24 hours was analysed for all stations. The back trajectory analysis (Figure 14) shows that the air mass originated in the Waterberg region directly over the town of Lephalale, which is the location of a large coal fired power station, it then moved due south, passing over the Bojanala District and the Platinum mining activities in the region before passing over the gold mining region of Randfontein, located to the west of Johannesburg. During the time of the elevated ozone concentration the wind at the monitoring stations was from the north-west and north-north-west with a wind speed of between $5.7 \mathrm{~m} / \mathrm{s}$ to $11 \mathrm{~m} / \mathrm{s}$ (Figure 15 ).

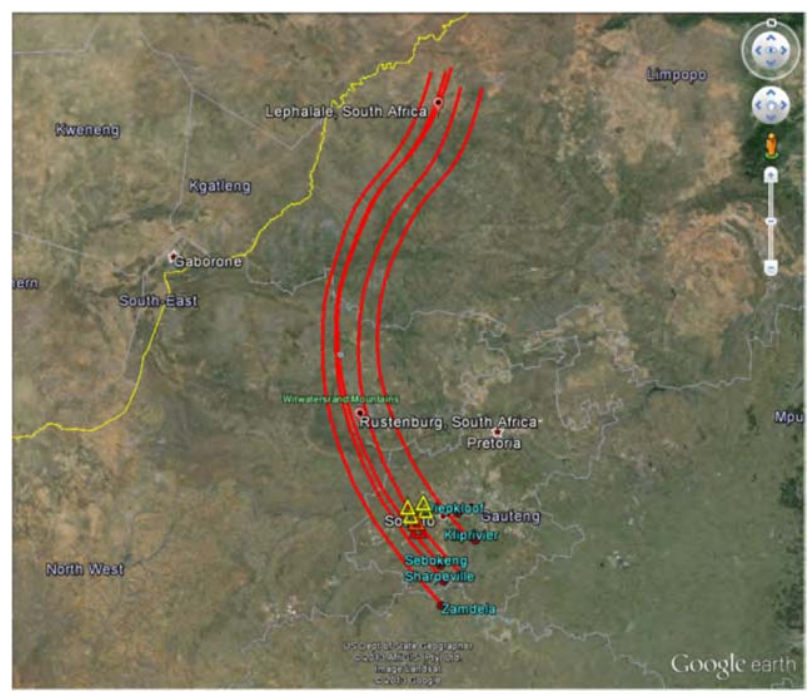

Figure 1424 hour back trajectory analysis for the stations recording elevated ozone

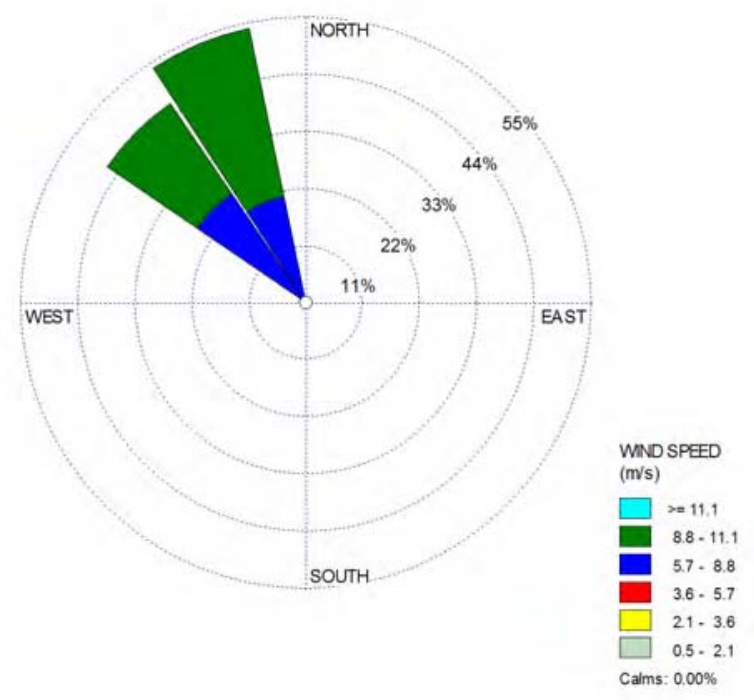

Figure 15 Wind-rose, Sebokeng station for the period 9:00 - 16:00 


\subsection{Fire Occurrence}

Satellite Information from EUMETSAT MSG was used to identify the location and intensity of veld fires in the region which may have impacted on the production of ozone precursors and ultimately resulted in the extremely high concentrations of tropospheric ozone that were observed over some of the stations in the Vaal Triangle on the 2 June 2013. During the second of June there was considerable biomass burning in the central regions of South Africa. Figure 13 shows the EUMETSAT MSG output over the Vaal Triangle region. Of those fires, six were within the direct path of the air mass that carried the high ozone concentration those being the fires located to the north west of the stations as shown in Figure 16.

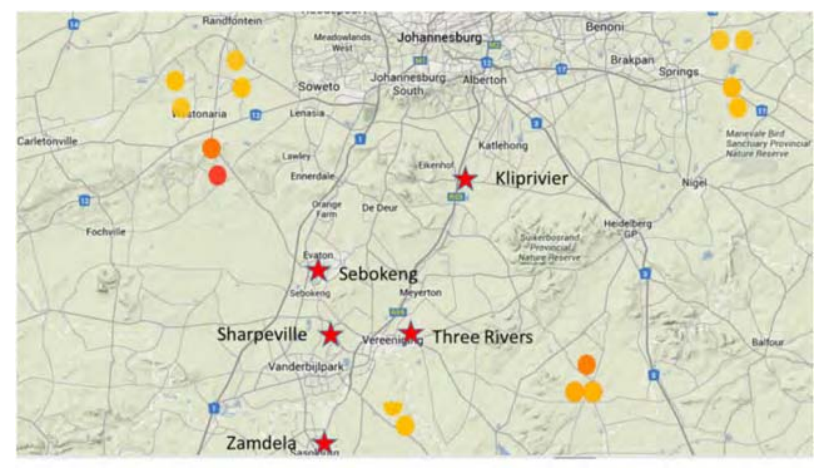

Figure 16 Occurrence of wild fires over Vaal Triangle Region on the 2nd June 2013

\section{Discussion}

The period of high ozone concentrations that was reported at some of the stations in the Vaal Triangle on the $2^{\text {nd }}$ of June 2013 is unusual in terms of the magnitude of the increase in the ozone concentration. The peak in the ozone concentration is associated with increases in the concentrations of particulate matter, especially of the $\mathrm{PM}_{10}$ size classes, but also the concentration of black carbon. The concentrations of $\mathrm{CO}, \mathrm{SO}_{2}, \mathrm{NO}_{x}$ and benzene did not show significant changes associated with the elevation in ozone concentration. Back trajectory analysis indicates three potential sources for the ozone precursors that fell within the path of the air mass arriving at the monitoring stations. Those include; 6 wild fires that were active $30 \mathrm{~km}$ to $40 \mathrm{~km}$ to the north west of the monitoring stations, the mineral processing activity in the Bojanala district surrounding Rustenburg and the coal fired power station at Lephalale approximately $300 \mathrm{~km}$ to the north of the monitoring stations where the air mass originated 24 hours previously.

Analysis of the corresponding concentrations of other pollutants provides some indication as to which of the potential sources of the precursors is responsible for the high ozone concentrations reported on the day. It is expected that if the source of the ozone precursors responsible for the formation of the ozone peak observed at the Sharpeville, Sebokeng and Zamdela stations was due to industrial activity such as the combustion of coal or the processing of sulphate rich minerals, the peak in ozone concentration would be associated with increases in the concentrations of $\mathrm{SO}_{2}$ and $\mathrm{NO}_{x}$. This however did not occur. It is known that the $\mathrm{NO}_{x}$ and $\mathrm{SO}_{2}$ in power station plumes can be removed rapidly through chemical processing (Zhou et al., 2012). The $\mathrm{SO}_{2}$ and $\mathrm{NO}_{x}$ loss is reported to be greater under cloudy conditions.

However if the production of ozone is associated with a biomass combustion source the ozone peak would associated with increases in the concentrations of PM and specifically black carbon as a product of incomplete combustion. In this case the temporal changes in the concentration of the other monitored pollutant indicate that the source of the ozone precursors is likely to be biomass burning. The wind direction and location of fires in the Vaal Triangle region strengthen this explanation. Analysis of ozone production in African biomass burning plumes, has reported elevations of the ozone concentration of up to $98 \mathrm{ppb} 18 \mathrm{~km}$ downwind of savanna fires in South Africa(Yokelson et al., 2003).

\section{Conclusion}

The management of ambient air quality in complex environments such as the Vaal Triangle can be difficult; this is especially true for secondary pollutants such as ozone, which are formed through the interaction of numerous chemical precursors and the environmental conditions. This study presents an analysis of the chemical and environmental conditions during a period of extremely high ozone concentration. Evidence suggests that biomass burning played an important role in the period of elevated ozone, but other factors such as the long range transport of precursors from power generation and mineral processing activities may have played a role in allowing for such high concentrations of ozone to be formed. Further modelling to better understand the chemical processes and the precursor concentration requirements would help in understanding the processes that occurred and identify the precursor sources, thus enabling focused management interventions on the local or regional scales.

\section{References}

Chameides, W. L., Fehsenfeld, F., Rodgers, M. O., Cardonelino, C., Martinez, J., Parrish.D, ... Wang, T. (1992). Ozone Precursor Relationships in the Ambient Atmosphere. Journal of geophysical Research, 97(91), 60376055. doi:01480227/92/9IJD-03014\$05.00

Crutzen, P. J., \& Lelieveld, J. (2001). Human impacts on atmospheric chemistry. Annual Review of Earth and Planetary Sciences, 29(1), 1745. Retrieved from http://www.annualreviews.org/doi/abs/10.1146/annu 
rev.earth.29.1.17

DEA. (2009). National Ambient Air Quality Standards. Government Gazette, 4.

SANAS. (2012). Tr 07-03 Supplementary Requirements for the Accreditation of Continuous Ambient Air Quality Monitoring Stations (pp. 112).

SAWS. (2013). Daily Weather Bulletin 2 June 2013 (p. 2). Pretoria.

Seinfeld, J. H., \& Pandis, S. N. (2006). Atmospheric Chemistry and Physics (2nd ed., p. 1203). Hoboken: John Wiley and Sons.

Silva, R. a, West, J. J., Zhang, Y., Anenberg, S. C., Lamarque, J.-F., Shindell, D. T., ... Zeng, G. (2013). Global premature mortality due to anthropogenic outdoor air pollution and the contribution of past climate change. Environmental Research Letters, 8, 034005. doi:10.1088/1748-9326/8/3/034005

Trade and Industry Chamber. (2004). Funds for Research into Industrial Development Growth and Equity (FRIDGE) Study to examine the potential socia-economic impact of measures to reduce air pollution from combustion.
Van Rooi, W. (2012). Advanced Fire Information $\mathrm{S}$ y s t e m . R e t r i e v e f r o m http://www.techtransfer.csir.co.za/2012/09/advanced -fire-information-system/

WHO. (2013). "Review of evidence on health aspects of air pollution REVIHAAP" (p. 29). Retrieved from http://www.euro.who.int/_data/assets/pdf_file/0020/ 182432/e96762-final.pdf

Yokelson, R. J., Bertschi, I. T., Christian, T. J., Hobbs, P. V, Ward, D. E., \& Hao, W. M. (2003). Trace gas measurements in nascent, aged, and cloudprocessed smoke from African savanna fires by airborne Fourier transform infrared spectroscopy ( AFTIR ). Journal of Geophysical Research, 108(D13), 8478. doi:10.1029/2002JD002322

Zhou, W., Cohan, D. S., Pinder, R. W., Neuman, J. a., Holloway, J. S., Peischl, J., ... Zheng, W. G. (2012). Observation and modeling of the evolution of Texas power plant plumes. Atmospheric Chemistry and Physics, 12(1), 455468. doi:10.5194/acp-12-4552012
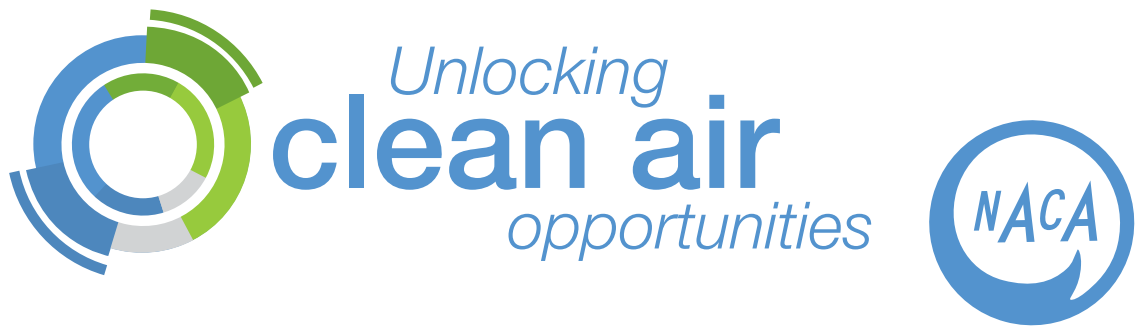

2014 Conference of the National Association for Clean Air 9 - 10 October, Umhlanga, KwaZulu-Natal

\section{CONFERENCE WEBSITE \& REGISTRATION OPEN 1 JUNE 2014}

The Organising Committee of the 2014 NACA Conference invites submissions of papers for the annual conference of the National Association for Clean Air, to be held at The Gateway Hotel, Umhlanga, KwaZulu-Natal, South Africa from 9-10 October 2014. The Conference will follow immediately after the Department of Environmental Affairs' Air Quality Governance Lekgotla, and the joint DEA/NACA workshop.

The theme for this year's conference is "Unlocking Clean Air Opportunities" with the following sub-themes:
- Urban and industrial air quality
- Climate change mitigation
- Air quality governance

- Air quality monitoring and modelling

The conference is intended to focus on the pro-active management of air quality issues in the country and SADC region. In particular, the focus is on the preservation of areas of 'pristine' air quality and strides in the prevention of future air quality issues. Opportunities for innovative management, partnerships, and timely intervention in areas of poor or potentially poor air quality will provide participants with knowledge at the forefront of air quality management in the region.

\section{CALL FOR PAPERS}

Presenters are requested to register and submit their abstracts on the electronic submission and evaluation system. Guidelines for papers and posters are available on the conference page of the NACA website (www.naca.org.za).

Papers will be peer-reviewed by a Scientific Review Committee and published in the electronic conference proceedings and on the NACA website. The Committee reserves the right to reject any abstract or paper considered not to meet the conference criteria. Selected papers may be published in NACA Journal.

\section{DEADLINES}

Abstract submission

23 June 2014

Notification of acceptance of abstracts

4 July 2014

Full papers due

4 August 2014

Notification of acceptance and

comments on papers

22 August 2014

Submission of final papers, for inclusion in the electronic conference proceedings

15 September 2014

For abstract submission requirements and further instructions, please visit

www.naca.org.za 